\section{鰹だし継続摂取が気分・感情状態, 特に疲労感に及ぼす影響}

\author{
石崎太一，黒田素央 ${ }^{\S}$, 杉田正明* \\ 味の素株式会社 \\ *三重大学教育学部
}

The Effect of Dried Skipjack Soup Stock on Mood and

Emotional States, Especially the Fatigue State

Taichi Ishizaki, Motonaka Kuroda ${ }^{\S}$ and Masaaki Sugita*

Ajinomoto Co., Inc., 1-1 Suzuki-cho, Kawasaki-ku,

Kawasaki-shi, Kanagawa 210-8681

* Mie University, 1515 Kamihama-cho, Tsu-shi, Mie 514-8507

\begin{abstract}
Using a placebo-controlled single blind study, we examined the effect of dried skipjack soup stock (DSSS) on the mood and emotional states of middle-aged Japanese subjects. Thirty-eight subjects (19 female, 19 male) were divided into two groups, and one group consumed "miso soup" containing $5.0 \mathrm{~g} /$ day of DSSS (test group), and the other group consumed "miso soup" without DSSS (placebo group) for 2 weeks. In the analysis performed on all subjects, the eye fatigue score of the emotional questionnaire $(\mathrm{EQ})$ significantly decreased in week $1(\mathrm{p}<0.05)$, and the depression score of the profile of mood states (POMS) significantly decreased in week $2(\mathrm{p}<0.05)$ for the Test group. In the analysis performed on subjects who had fatigue symptoms, the fatigue score and the concentration score of the EQ significantly decreased (improved) in the Test group $(\mathrm{p}<0.05)$. The tension score of POMS significantly decreased $(\mathrm{p}<0.05)$ in the Test group. The TMD change in the Test group was significantly lower than that of Placebo group $(p<0.05)$. These results suggested that the intake of DSSS has a beneficial effect on the moods and emotional states of middle-aged Japanese. (Received Aug. 11, 2005 ; Accepted Jan. 10, 2006)
\end{abstract}

鰹節は古来よりわが国において，だしの原料として用い られている素材である. 鰹だしは, その特有の呈味と風味 の好ましさから, 広く日本料理の味のベースとして用いら れてきた。 また，一方で，沖縄の「鰹湯（カチューュ)」や 鹿児島の「茶節」の例に見られるように, 鰹節あるいは鰹 だしは古来より滋養強壮効果や疲労回復効果があると伝承 的に言われている。そそこで, 我々は鰹だしの生理機能評価 について疲労に対する影響を中心に研究を行ってきた。

７210-8681 神奈川県川崎市川崎区鈴木町 1-1

* $=514-8507$ 三重県津市上浜町 1515

§連絡先 (Corresponding author), motonaka_kuroda@ajinomoto.com 黒田素央 TEL 044-244-7156 FAX 044-244-4348
動物試験においては，マウスを回転車にて強制歩行させ た後に赤外線センサーにて自発運動量を測定する試験系で 䚫だしを与えると自発運動量が高くなること1)や，マウス を流水式プールにて強制遊泳させた時の遊泳可能時間を測 定する試験系で鰹エキスを与えると遊泳時間が延長するこ と2) 確認している。 また，上卜においては，女子大生を対 象として, 鰹だしを継続摂取させた前後に, POMS（詳細 は方法にて後述）を実施したところ鰹だし摂取により気分 感情状態が良好になること ${ }^{3)}$, 単純作業負荷時の疲労感や ストレスマーカーの上昇が軽減されること4)について，報 告している.

上記に示したヒトでの効果は鰹だしを料理に用いるなど の日常的な摂取形態と異なり, 鰹だしを飲料の様に摂取し た試験であった。そこで，本検討では鰹だしを日常的に摂 取しうる形態 (味増汁) で継続摂取した時に, 鰹だしが気 分・感情に及ぼす影響を中高年の男女を対象として, 評価 した。

\section{1. 実験方法}

(1) 被験者

三重大学に在籍する職員で自発的に本調查への参加を文 書にて申し出た 38 名を対象とした。な扔, 本試験はへルシ ンキ宣言の精神に則り, 被験者に研究の趣旨および試験内 容を充分に説明し同意の得られた被験者で行った。年齢, 身長, 体重及び気分アンケート（後述）における「疲労感」 において群間に差が無い様に 2 群に分けた。すなわち，プ 亏セボ群 19 名 (男性 11 名, 女性 8 名; 年齢 $44.9 \pm 2.0$ 歳, 身長 $161.8 \pm 2.1 \mathrm{~cm}$, 体重 $57.5 \pm 2.5 \mathrm{~kg}$, 疲労感スコア $2.9 \pm$ 0.3 点), 鰹だし群 19 名 (男性 11 名, 女性 8 名; 年齢 $43.1 \pm$ 1.9 歳, 身長 $161.5 \pm 1.9 \mathrm{~cm}$, 体重 $56.9 \pm 2.4 \mathrm{~kg}$, 疲労感スコ ア $3.0 \pm 0.3$ 点）とした。数值は平均土標準誤差を示す.

(2) 被験食掞よび摂取方法

表 1 亿試験食組成を示した。鰹だし含有味増汁（以下， 鰹だし) は，粉末味噌に乾燥させた業務用鰹だし（「一番だ し」かつお，味の素(株)製）を添加して調製した。対照味 噌汁（以下，プラセボ）は外観と呈味を合わせる為にグラ ニュー糖, 食塩, 調味料, 鰹節フレーバー粉末を粉末味噌 に加えて調製した。鰹節フレーバー粉末は, 鰹だしと同産 地の鰹節を原料として香気成分を液化炭酸ガスで効率的に 抽出した後に乾燥したものである ${ }^{5}$. 被験食は 1 食分をア ルミパックで包装し, 朝夕に 1 袋ずつ, 2 週間摂取させた.

(3) 評価指標

(1) 気分アンケート

被験食摂取の開始時, 1 週間, 終了時及び摂取開始前の 募集期間に実施した。アンケートは,「疲労感」「体力」, 「立ちくらみ」,「風邪」,「睡眠」,「寝起き」,「食欲」,「肩こ り」,「腰痛」,「眼の疲れ」,「体のむくみ」,「集中力」の 12 項目からなり, 5 点法で答える形とした。なお, 得点が低い ほど気分・感情の状態が良好であることを示す。 
表 1 被験食の組成（1 食当り）

\begin{tabular}{lccc}
\hline \hline & 単位 & プラセボ & 鰹だし \\
\hline 粉末味増 & $\mathrm{g}$ & 5.37 & 5.22 \\
グルタミン酸ナトリウム & $\mathrm{g}$ & 0.47 & 0.00 \\
イノシン酸ナトリウム & $\mathrm{g}$ & 0.07 & 0.00 \\
グラニュー糖 & $\mathrm{g}$ & 0.46 & 0.00 \\
鰹節フレーバー粉末 & $\mathrm{g}$ & 0.22 & 0.00 \\
デキストリン & $\mathrm{g}$ & 2.57 & 2.49 \\
食塩 & $\mathrm{g}$ & 0.15 & 0.00 \\
鰹だし乾燥粉末 ${ }^{(*)}$ & $\mathrm{g}$ & 0.00 & 2.49 \\
\hline 合計 & & 9.30 & 10.20 \\
\hline (*)「本造り一番だし」かつお (味の素(株) 製) を乾燥させたもの
\end{tabular}

(*)「本造り一番だし」かつお (味の素(株) 製)を乾燥させたもの

(2) POMS (Profile of Mood States) $)^{6)}$

試験食摂取の開始時と終了時に実施した。本報告におい ては，全国平均を 50 点とし換算する気分プロフィール換 算表を用い標準化得点にて示した7). 試験用紙は日本版 POMS-No. 851 (金子書房)を用いた.

(3) 歩行量調查

摂取期間中に実施した。測定機器による差を無くす為 に, 同一の万歩計 (Lifecorder EX (株) スズケン製) ${ }^{8}$ を使 用した。 また，本装置は振幅の大きさの加速度を測定する 事や体格から運動量及び消費エネルギーの算出機能を有し ているので，それらあ合わせて評価を行った．

(4) 生活状況アンケート

掑取期間終了時に試験前と比べて, 生活状況（食事量, 飲酒量, 睡眠時間) 変化があったか確認するアンケート調 查を実施した。

(4) 統計解析

全ての測定值は, 平均值士標準偏差で示した。気分アン ケートについて, 群内変化は Wilcoxon の符号付順位検定 を実施し, 群間比較については Mann-Whitney の U 検定 にて実施した。他の項目について, 群内変化は paired t-test を実施し，群間比較は $\mathrm{F}$ 検定にて有意差が見られな かった場合において Student t-test を実施し，F 検定にて 有意差が見られた場合において Welch 検定を実施した。 いずれも両側検定で有意水準を危険率 $5 \%$ 以下とした。

\section{2. 実験結果および考察}

(1) 生活状況の変化

摂取期間中における生活の状況（食事量, 飲酒量, 睡眠 時間）の増減に関するアンケート調査の結果, 食事量は鰹 だし群, プラセボ群共に 3 名が増加したと回答したが, 群 間での差はなかった。また, 飲酒量, 睡眠時間についても 1 2 名が増加又は減少と回答しただけであり, 群間におけ る顕著な差は認められなかった。摂取期間中の消費エネル ギー量を測定した結果, 群間における有意な差は認められ なかった（プラセボ群；1 $762 \pm 72 \mathrm{kcal} /$ 日, 鰹だし群; $1793 \pm 63 \mathrm{kcal} /$ 日, 平均土標準誤差). 以上より, 被験食の
摂取期間中に生活習慣の变化はなく, 群間における差も無 いと考えられた.

（2）気分・感情の変化

(1) 全被験者に打ける解析

気分アンケートの結果を以下に示す。結果は平均土標準 誤差を示す.「立ちくらみ」において, プラセボ群のみ 2 週 間目に有意に低下した（開始時 $2.4 \pm 0.2,2$ 週間後 $1.8 \pm 0.2$; $\mathrm{p}<0.05)$.「眼の疲れ」において，プラセボ群は摂取期間中 に殆ど変化しないのに対し, 鰹だし群は摂取 1 週目で有意 に低下し(開始時 $3.6 \pm 0.2,1$ 週間後 $3.1 \pm 0.2 ; \mathrm{p}<0.05$ ), 終 了時（3.2土0.3）あ下がったまま推移したが，2 週間目の值 については開始時に対する有意な差は見られなかった。表 2 にPOMS の結果を示した。「抑うつ一落込み」において鰹 だし群は有意に低下した（ $<<0.05) 。$ 一方，プラセボ群に ついてはいずれの項目においても有意な変化は見られな かった。

(2) 疲労感を自覚している被験者について

今回の調査は, 疲労感を自覚している被験者に及ぼす影 響の評価が重要であると考えられる。 そこで, 開始時の気 分アンケートの「疲労感」のスコアが 4 以上 $(4$; やや感じ る, 5 ; 常に感じる) を示した被験者（プラセボ群 8 名, 鰹 だし群 7 名）を対象として解析した。気分アンケートの結 果, 「疲労感」において, プラセボ群は開始時から終了時に かけて有意に低下した（開始時 $4.4 \pm 0.2,2$ 週間後 $3.1 \pm 0.3$; $\mathrm{p}<0.05 ）$ が，鰹だし群は 1 週目及び終了時の両方において 有意に低下した（開始時 $4.0 \pm 0.0,1$ 週間後 $3.0 \pm 0.2,2$ 週 間後 $2.7 \pm 0.2 ;$ ともに $\mathrm{p}<0.05)$.「立ちくらみ」に扔いて, プラセボ群は 2 週間後に有意に低下した（開始時 $3.1 \pm 0.4$, 2 週間後 $2.1 \pm 0.4 ; \mathrm{p}<0.05)$.「集中力」スコアに扔いて, 鰹 だし群は開始時から終了時に有意に低下した（開始時 3.1 $\pm 0.3,2$ 週間後 $2.6 \pm 0.3 ; \mathrm{p}<0.05)$.すなわち, 「集中力」が 有意に改善した. 表 3 にPOMS の結果を示した.「緊張一不 安」において, 鰹だし群は開始時から終了時にかけて有意 に低下した $(\mathrm{p}<0.05)$.「疲労」において, 鰹だし群は開始 時から終了時にかけて低下する傾向 $(p<0.1)$ を示した. また，総合的な感情を表す指標である TMD（Total Mood Disturbance; 総合感情障害) ${ }^{9110)}$ においても，鰹だし群は 開始時から終了時にかけて低下する傾向を示した $(\mathrm{p}<0.1)$. 変化量について着目すると, TMD において鰹だし群はプ ラセボ群よりも有意に低值を示した（ $\mathrm{p}<0.05)$ ，一方，プ ラセボ群では有意あるいは有意傾向で変化する項目は見ら れなかった. 以上の結果から, 疲労感の高い被験者に対し て, 鰹だし摂取により気分・感情状態が改善する可能性が 示唆された。但し, 疲労感の高い被験者を対象とした解析 については被験者数が少ないため, 今後, より多くの被験 者を対象として確認する必要がある。また，全被験者を対 象とした結果（表 2）と疲労感の高い被験者を対象とした 結果 (表 3) を比較すると, 後者においてより多くの項目で 
表 2 POMS スコアの推移（全被験者）

\begin{tabular}{llccc}
\hline \hline & & 開始時 & 終了時 & 変化量 \\
\hline \multirow{2}{*}{ 緊張-不安 } & プラセボ & $52.1 \pm 2.0$ & $50.1 \pm 2.2$ & $-1.9 \pm 1.8$ \\
& 鰹だし & $55.1 \pm 2.4$ & $51.8 \pm 2.6$ & $-3.3 \pm 1.8$ \\
抑うつ一落込み & プラセボ & $53.4 \pm 3.0$ & $52.4 \pm 2.8$ & $-0.9 \pm 1.0$ \\
& 鰹だし & $58.2 \pm 2.9$ & $54.4 \pm 2.7 *$ & $-3.8 \pm 1.5$ \\
怒り-敵意 & プラセボ & $49.2 \pm 2.1$ & $50.3 \pm 2.3$ & $1.2 \pm 1.5$ \\
& 鰹だし & $50.2 \pm 2.2$ & $50.4 \pm 2.2$ & $0.2 \pm 1.2$ \\
活気 & プラセボ & $45.3 \pm 2.4$ & $45.2 \pm 2.7$ & $-0.1 \pm 1.6$ \\
& 鰹だし & $43.7 \pm 2.1$ & $43.8 \pm 1.7$ & $0.1 \pm 2.4$ \\
疲労 & プラセボ & $52.0 \pm 2.3$ & $52.4 \pm 2.5$ & $0.4 \pm 2.1$ \\
& 鰹だし & $51.0 \pm 1.7$ & $50.9 \pm 2.3$ & $-0.1 \pm 2.1$ \\
混乱 & プラセボ & $52.5 \pm 2.6$ & $53.4 \pm 2.4$ & $0.9 \pm 2.2$ \\
& 鰹だし & $58.7 \pm 2.5$ & $55.8 \pm 2.5$ & $-2.8 \pm 2.0$ \\
\hline \multirow{2}{*}{ TMD } & プラセボ & $213.8 \pm 11.0$ & $213.5 \pm 11.1$ & $-0.4 \pm 5.2$ \\
& 鰹だし & $229.5 \pm 10.1$ & $219.5 \pm 10.4$ & $-9.9 \pm 6.0$ \\
\hline
\end{tabular}

・平均值士標準誤差, プラセボ $\mathrm{n}=19$, 鰹だし $\mathrm{n}=19$

・開始時からの有意な変化あり。 ${ }^{*} ; \mathrm{p}<0.05$.

表 $3 \quad$ POMS スコアの推移（疲労感の高い被験者）

\begin{tabular}{|c|c|c|c|c|c|c|}
\hline & & 開始時 & 終了時 & & 変化量 & \\
\hline \multirow{2}{*}{ 緊張-不安 } & プラセボ & $54.9 \pm 3.1$ & $55.3 \pm 4.3$ & & $0.4 \pm 2.9$ & \\
\hline & 鰹だし & $55.1 \pm 3.2$ & $49.4 \pm 2.6$ & & $-5.7 \pm 2.2$ & \\
\hline \multirow{2}{*}{ 抑うつ-落込み } & プラセボ & $58.9 \pm 6.1$ & $59.0 \pm 5.5$ & & $0.1 \pm 1.7$ & \\
\hline & 鰹だし & $60.6 \pm 6.0$ & $57.0 \pm 4.3$ & & $-3.6 \pm 2.4$ & \\
\hline \multirow{2}{*}{ 怒り-敵意 } & プラセボ & $52.4 \pm 3.8$ & $53.8 \pm 3.7$ & & $1.4 \pm 2.3$ & \\
\hline & 鰹だし & $49.9 \pm 3.6$ & $50.4 \pm 3.2$ & & $0.6 \pm 1.4$ & \\
\hline \multirow{2}{*}{ 活気 } & プラセボ & $40.9 \pm 2.6$ & $40.5 \pm 3.0$ & \multirow{2}{*}{$\mathrm{p}=0.099$} & $-0.4 \pm 3.4$ & \\
\hline & 鰹だし & $44.6 \pm 2.0$ & $47.6 \pm 2.5$ & & $3.0 \pm 2.9$ & \\
\hline \multirow{2}{*}{ 疲労 } & プラセボ & $56.9 \pm 3.4$ & $55.1 \pm 3.3$ & \multirow{4}{*}{$\mathrm{p}=0.053$} & $-1.8 \pm 1.5$ & \\
\hline & 鰹だし & $54.7 \pm 2.4$ & $50.3 \pm 2.2$ & & $-4.4 \pm 1.9$ & \\
\hline \multirow{2}{*}{ 混乱 } & プラセボ & $54.8 \pm 4.2$ & $58.8 \pm 4.2$ & & $4.0 \pm 4.3$ & \\
\hline & 鰹だし & $58.6 \pm 3.4$ & $55.3 \pm 2.7$ & & $-3.3 \pm 1.8$ & \\
\hline \multirow{2}{*}{ TMD } & プラセボ & $236.9 \pm 20.2$ & $241.4 \pm 19.0$ & \multirow[b]{2}{*}{$\mathrm{p}=0.057$} & $4.5 \pm 7.0$ & \multirow{2}{*}{$\#$} \\
\hline & 鰹だし & $234.3 \pm 14.0$ & $214.9 \pm 10.0$ & & $-19.4 \pm 8.1$ & \\
\hline
\end{tabular}

・平均值士標準誤差, プラセボ $\mathrm{n}=8$, 䚚だし $\mathrm{n}=7$

・開始時からの有意な変化あり。 ${ }^{*} ; \mathrm{p}<0.05$.

・群間に有意差あり。 \#; $<<0.05$.

鰹だし摂取時に有意，あるいは有意傾向の改善が見られる こと，および TMD の变化量において鰹だし群がプラセボ 群より有意に低值を示したことから, 疲労感を強く感じて いる被験者のほうが鰹だし摂取の効果が表れやすいと推測 された。なお，鏗だしが気分・感情に良い影響を与えるメ カニズムについては不明であるが，摂取直後ではなく継続 摂取した際の効果であることから，風味や香りなどによる 一時的なリラックス効果ではなく，水溶性成分による作用 であると考えられる，㙰だしには，抗酸化機能を有するア ミノ酸・ペプチドであるヒスチジン・アンセリンなどが多 く含有されている。アンセリン・ヒスチジンを高含有する 鰹エキス素材の摂取により,「眼の疲れ」「疲労感」が改善

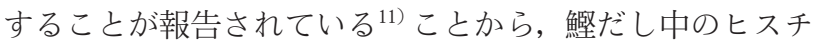
ジンやアンセリンなどが寄与している可能性も考えられ
る.しかし，有効成分の検索抒よび作用メカニズムの解析 については今後の課題と考えられる.

\section{3. 要 約}

プラセボ食群を対照とした，シングルブラインドの 2 群 並行試験により，中高年の気分・感情状態に対する鰹だし 継続摂取の影響について調査を行った。全被験者を対象と した解析の結果, 鏗だし摂取により「眼の疲れ」, POMS の 「抑うつ-落込み」得点が有意に低下 (改善) することが示 された。疲労感を自覚している被験者を対象とした解析の 結果，気分アンケートの「疲労感」「集中力」の項目にお いて, 鰹だし群は摂取時に有意に低下（改善）した。また, POMS について, 鰹だし群は「緊張一不安」において有意に 低下し, また, TMD (総合感情障害指標) 変化量において 鰹だし群はプラセボ群よりも有意に低值を示した。すなわ 
ち, 䚚だし群はプラセボ群と比較して有意に TMD が改善 することが示唆された。これらの結果から，味噌汁形態で 鰹だしを摂取した時に, 気分・感情状態が改善する可能性 が示唆された。

本研究を遂行するにあたり, 東京大学大学院新領域創成 科学研究科大谷勝教授には, 試験計画の作成やデー夕解析 に際して, 多大なご助言を頂きました。また, 味の素株式 会社アミノバイタル部（現アミノ酸カンパニーアミノ酸コ ンシュマープロダクト部) 小笠原和子氏に, 試験運営にお いて多大なご協力を頂きました，厚く御礼申し上げます.

\section{文献}

1）村上仁志，鰹だしの疲労回復効果，化学と工業， 57, 522524 (2004).

2）野沢与志津, 山田桂子, 石崎太一, 黒田素央, 強制遊泳系に 扮ける鰹熱水抽出物の抗疲労効果について, 第 59 回日本体 力医学会大会予稿集, p. 253, さいたま (2004).

3）石崎太一, 久野真奈見, 梅木陽子, 黒田素央, 早㴊仁美, 了 ンケート形式 (POMS) による鰹だし摂取の気分・感情に 及ぼす影響の調査, 日本食生活学会誌，16，39-43（2005）.

4）石崎太一, 黒田素央, 北面美穂, 久野真奈見, 早㴊仁美, 鰹 だし継続摂取が単純作業負荷時のストレスや作業能力に及
ぼす影響, 第 59 回日本栄養・食糧学会講演要旨集, p. 143, 東京 (2005).

5）黑田素央, 各種調味料のレトルト加熱食品への利用, ジャ パンフードサイエンス，39，55（2002）.

6）横山和仁, 荒木俊一, 川上憲人, 竹下達也, POMS（感情プ ロフィール検查）日本語版の作成と信頼性打よび妥当性の 検討，日本公衆衛生雑誌，37，913-918 (1990).

7）横山和仁，荒木俊一，岡島史佳，野村 忍，奥山富男， POMS（感情プロフィール検査）日本語版の訳語ならびに 短縮版の検討，日本公衆衛生雑誌，39，900（1993）。

8) Saito, N., Yamamoto, T., Sugiura, Y., Shimizu, S. and Shimizu, M., Lifecorder, Internal Medicine, 43, 685 (2004).

9) Dyer, K.R., White, J.M., Foster, D.J., Bochener, F., Menelaou, A. and Somogy, A., The relationship between mode state and plasma methadone concentration in maintenance patients, J. Clin. Psychopharmcol. 21, 7884 (2001).

10）脇屋太一，梅田 孝, 益子俊志, 檀上和真, 鈴木雅博, 中路 重之, 菅原和夫, 大学ラグビー選手の試合後の身体的, 心理 的疲労に関する研究, 体力・栄養 - 免疫学雑誌, 12, 10-16 (2002).

11）菊池和晃, 又平芳春, 岡田 守, アンセリン含有食品「マリ ンアクティブ」の継続摂取が疲労感に及ぼす影響, 新薬と 臨床，51，525-530 (2002).

(平成 17 年 8 月 11 日受付, 平成 18 年 1 月 10 日受理) 